\title{
Suvi Labtonen
}

\section{Ulla-Lena Lundbergin Marsipansoldaten sotaromaanina ja ruokakuvauksena}

[--] inför Aeolus smörgåsbord pickar hjärtat räddhågat i barmen på honom. Framför honom ligger uppskärningar och inläggningar som han aldrig förr har sett och inte vet hur han ska tackla. Han vet bara hur han skulle fă allt att gå till väders med en välriktad handgranat, men hur och vad man ska äta och i vilken ordning utan att väcka uppseende har armén aldrig förberett honom på. [--] Framryckning. Tallrik i näven. Långsamt avancemang längs raden av skålar och fat. Stadigt grepp om skeden, kombination av knyck och skakning, och på tallriken landar: strömmingsrullader i ättikslag, kryddsill, rökt sik, kokta kräftor, skinka, saltkött, sallat i grädd- och äggsås, ärtstuvning, potatissallad, kalla små köttbullar utan sås, små kokta morötter, ättiksgurka, tomatskivor med råa lökringar. $\mathrm{Nu}$ full last på tallriken. (M 386.) $)^{1}$

Vuonna 2012 Ulla-Lena Lundberg sai Finlandia-palkinnon romaanistaan $I s$, joka on vuonna 2001 ilmestyneen Marsipansoldaten-romaanin itsenäinen jatko-osa. Tarkastelen tässä artikkelissa Lundbergin julkaisusyksynään runsaasti keskustelua herättänyttä romaania Marsipansoldaten ja sen suhdetta suomalaisen sotaromaanin lajiin sekä sen groteskia ruokakuvausta. Osoitan, kuinka romaanissa groteski kuvasto liittää teoksen perinteiseksi miellettyyn kotimaiseen sotafiktioon, kytkee teoksen nuoruuteen sekä korostaa yksityistä selviytymistä yhteiskunnallisessa kriisissä.

Marsipansoldaten kuvaa toisen maailmansodan aikaista Suomea Kummelin kuusihenkisen perheen näkökulmasta. Vanhemmat Martha ja Leonard, papiksi opiskeleva esikoispoika Petter ja kuopus Charlotte seuraavat kahden keskimmäisen pojan, Frejn ja Göranin, vaiheita toiminnallisessa sodassa ja osallistuvat itse aktiivisesti kotirintaman sotaan. Yhteisökuvaukseksi laventuva romaani tarjoaa useita leikkauspintoja sodassa tiivistyvään yhteiskuntamurrokseen: henkilöhahmojen lukuisuus avaa sotakokemusten kirjon ja ajankuva on runsas esineitä ja ajan eetosta myöten. Romaani rinnastaa tasapuolisesti kotirintaman siviilielämän ja sotilaiden kenttäkokemukset. Jo pelkästään tämä piirre vei kotimaista sotafiktiota uuteen suuntaan romaanin ilmestyessä.

\section{Toiminnallisen sodan autenttisuusehto kotimaisessa sotafiktiossa ja sotaromaanin laajeneva kuva}

Suomalaisena sotaromaanina Marsipansoldaten on monessa mielessä uraauurtava. Se on suomenruotsalainen naisen kirjoittama sotakuvaus, joka on julkaistu 2000luvulla. Siinä luodaan kokonaiskuvaa sodasta perheen kautta: tarinan lähtökohtana 
on siis sota perheenjäsenten yksityisinä kokemuksina ja yksittäisten ihmisten vaiheet dramaattisen historiallisen yhteiskuntamurroksen aikaan.

Lajina suomalainen sotakirjallisuus on ideologisesti värittynyt ja voimakkaasti sidoksissa kansallisuuden esittämiseen. Kotimaisen sotafiktion dominoivana piirteenä on pidetty tosipohjaisuutta tai tekijän autenttista sotakokemusta, niin sanottua dokumentaarisuutta (Pilke 2009, 151; Niemi 1988, 162). Lisäksi suomalaiselle sotaromaanille on Juhani Niemen $(1988,29,70)$ mukaan tyypillistä tekstin pyrkimys ideologiattomuuteen tai muuten neutraaliin asenteeseen. Tämä ei kuitenkaan pidä täysin paikkaansa, koska sodan kytkös kansakunnan tai kansakuntaidentiteetin rakentumisen tarinaan pohjimmiltaan tuottaa sotafiktioon aina jonkinlaisen kytköksen tai kannanoton, puoltavan tai vastustavan, sodassa toiminnallistuviin ideologioihin. Näistä ideologioista nationalismi on näkyvin, mutta myös esimerkiksi maskulinismin ja pasifismin ideologiat ovat genressä läsnä.

Taistelun kuvaus, toiminta ja tulirintaman kuvauksen ensisijaisuus ja hierarkkinen ylemmyys kotirintaman ja siviilielämän kuvaukseen nähden on keskeistä kotimaisessa sotafiktiossa. Lajiin liittyvä, tyypillinen sotilaan hahmo on myös tarkkaan rajattu. Kotimainen sotilas on usein agraaritaustainen ja suomenkielinen, niin kutsuttu korpisotilas tai jänkäjääkäri (Mälkki 2008, 58, 259-260, 278, 295). Tässäkin mielessä Marsipansoldaten poikkeaa kotimaisen sotafiktion sotilaskuvauksesta - ovathan romaanin keskeisimmät hahmot, veljekset Göran ja Frej, länsiuusmaalaisia ruotsinkielisiä oppikoulu- ja ylioppilasnuorukaisia, jotka toimivat upseereina. Myös romaanin kerronnan jakautuminen melko tasaisesti muun perheen siviilielämän kuvauksen ja kahden keskimmäisen pojan toiminnallisen sotakuvauksen välillä on poikkeuksellista kotimaisten sotakuvausten joukossa.

Juhani Niemen mukaan sotaa käsittelevää kaunokirjallisuutta on usein pidetty enemmän ajanviete- kuin korkeakirjallisuutena. Kuitenkin siitä on erotettavissa korkeakirjallisuudelle tyypillisiä ohjelmallisia malleja, ja esimerkkinä Niemi (1988, 14-15) mainitsee realistisen ja modernistisen sotakuvauksen vastakkainasettelun. Sota on aiheena altis metaforisuudelle ja kun ajallinen etäisyys sotaan kasvaa, sen vertauskuvallisuus ja tekstuaalisuus korostuvat. (Niemi 1988, 16.)

Sodan kuvaamiselle ei Niemen mukaan ole olemassa yhtä estetiikkaa tai vakiintunutta ilmaisun tapaa. Tässä mielessä se ei poikkea muusta fiktiosta. Niemi $(1988,14)$ kuitenkin huomauttaa, että sodan niin kutsuttu ominaisluonne määrittää siitä kirjoittamista. Tulkitsen, että hän tarkoittaa tässä yhteydessä sotaa sekä toimintana, jossa keskeistä on taistelu, kuolema ja yhteisön tuhoutumisen uhka, että kronologisena tarinana, jossa on tärkeää, millaiseksi kokonaisnarratiivi voittoineen ja häviöineen kustakin sodasta muodostuu ja kenen näkökulmasta sodasta kerrotaan. Suomalaisessa toisen maailmansodan kuvausten tutkimisessa tämä merkitsee huomattavaa eroa talvisota- ja 
jatkosotakuvausten välillä. Talvisotakuvauksissa tutkitaan sitä, mikä on sotatilanteelle tyypillistä ja yleistä sodan lyhyen keston ja erityisen henkisyyden tai tunnelman, niin sanotun talvisodan pyhyyden tai talvisodan hengen (ks. esim. Mälkki 2008, 11-12), vuoksi. Jatkosotakuvauksissa keskeistä on usein toimintaa kuvaava kerronta, joka poikkeaa asemasodan puuduttavasta tapahtumattomuudesta, esimerkiksi tehtäväkeskeiset kaukopartiokertomukset ja jatkosodan lopun nopeat ja dramaattiset käänteet Kannaksella ja Lapissa. Sotakirjallisuudella on myös institutionaalisia piirteitä: se on osa kaanonia (esim. koululukemistoissa) ja siitä kirjoittavat kirjailijat ovat usein erikoistuneita sotaan aihepiirinä. (Niemi 1988, 16.)

Niemen kuvaus suomalaisesta sotakirjallisuudesta on osittain vanhentunut, ei ainoastaan julkaisuajankohtansa vuoksi, vaan myös siksi, että hän ennakoi sotakirjallisuuden vähittäistä hiipumista yleisön ja kirjailijoiden puutteessa (mt. 213). Tämä ei toistaiseksi ole pitänyt paikkaansa. Sotakirja lajina sekä sen lukijakunta on monipuolistunut 1990- ja 2000-luvuilla. Aikaisemmin etusijalla olivat kuvaukset taistelurintamakokemuksista ja etulinjan kuvaukset, nyt sotakuvauksen ainekseksi hyväksytään myös kotirintama- ja lapsuuskokemukset, minkä voi katsoa siirtymäksi laajempaan sodan kuvaan ja aiheen uudeksi lähestymistavaksi. Toiminnallista sotaa ja sen vaikutuksia sotilaiden siviilielämään ja siviilien elämään on sittemmin kuvattu ansiokkaasti useissa 2000-luvulla julkaistuissa kotimaisissa sotaromaaneissa, kuten esimerkiksi Sami Hilvon romaanissa Viinakortti (2010), Jenni Linturin romaanissa Isänmaan tähden (2011) ja Katja Ketun romaanissa Kätilö (2011).

Marsipansoldaten sijoittuu sotaromaanin perinteessä jatkosotakuvausten joukkoon: talvisodan aikana sotilasveljekset ovat koulutuksessa. Toiminnallinen sota alkaa Frejn kokemasta jatkosodan aloituksesta, jossa hän todistaa rautatieaseman pommitusta. Kohtaus on painokas myös siksi, että asema on paikka, jossa sotilas- ja siviilielämät risteävät. Rautatieaseman pommitus korostaa sitä, että sota ulottuu kaikkialle.

\section{Kotirintama ja huumori sotaromaanissa}

Kotirintamakuvaukset olivat harvinaisia sodan aikana ja heti sen jälkeen. Usein niitä ei sensuuriin vedoten edes julkaistu (Pilke 2009, 154). Siviilielämän kuvauksia ilmestyi vähitellen ja niiden voidaan katsoa yleistyneen vasta 1990-luvulla (Lahtonen 2011, 23). Martti Merenmaan Siivet kantavat (1940) ja Helmiriitta Setälän Juhanalan työtyttö (1944) ovat kotirintamakuvauksina poikkeuksia sotavuosina julkaistujen fiktioiden joukossa. Vanhimmat sodan lähikuviksi katsottavista tunnetuista siviilikuvauksista ilmestyivät yli kymmenen vuotta sodan päättymisen jälkeen (Siivet kantavat ja Juhanalan työtyttö poislukien). Paavo Rintalan Pojat ilmestyi vuonna 1958, ja Maria Jotunin vuonna 1942 kirjoittama pienoisromaani Evakuoidut julkaistiin postuumisti 
vasta vuonna 1966 (Lyytikäinen 2008, Lehto \& Rantanen 2008). Helvi Hämäläinen tarjosi helsinkiläispojista jatkosodan ja jälleenrakennuksen aikana kertovaa Raakileetromaania kustantajalleen vuonna 1950, mutta teos julkaistiin vasta vuonna 2007 (Kantokorpi 15.6.2007). Kotirintamakuvaukset ovat viime aikoihin asti ehkä myös kantaneet kaksinkertaista ajanvietteen leimaa: yhtältä siksi, että ne on mielletty naisten massaviihteeksi ${ }^{2}$ ja toisaalta siksi, että sotakirjoihin on suhtauduttu pejoratiivisesti ja niitä on pitkään pidetty viihteenä (Pilke 2009, 18-19, 26; myös Niemi). Sodan siviilikuvauksia on siis julkaistu säännöllisemmin vasta 1970-luvulta alkaen ja suurin osa on ilmestynyt 1990- ja 2000-luvuilla (vrt. Lehto \& Rantanen 2008, Lahtonen 2012, 24).

Sodan aikana ja välittömästi sodan jälkeen julkaistujen kotirintamakuvausten vähyyteen voi olla syynä myös syksyn 1944 välirauhansopimusta seurannut vuoteen 1946 kestänyt kirjakielto, joka siirsi enimmän osan sota-aiheisista kirjoista pois lukijoiden saatavilta. Tämä johti jonkinlaiseen itsesensuuriin kustantamoissa ja vaikutti välillisesti myös talvisota- ja jatkosotakirjallisuuden jakautumiseen: jatkosodan dramaattisia päätösvaiheita ei ehditty kirjoittaa ja julkaista, kun kielto oli jo voimassa. (Pilke 2009, 296.) Jatkosotakuvauksia jouduttiin siis pakostakin kypsyttelemään. Vuosien 1944-1946 kirjasensuuria tutkineen Kai Ekholmin mukaan kirjapoistojen vaikutus oli käytännössä vähäinen ja epätasainen; kirjoja oli edelleen saatavilla. Vaikutus kohdistui uusiin julkaisuihin. Kirjastoista poistettuja kirjoja oli saatavilla kaupoissa ja kodeissa, mutta sota aiheena lähes katosi julkaistujen kirjojen joukosta muutamaksi vuodeksi 1940-luvun lopulla ja 1950-luvun alussa. (Ekholm 2000, 126-136, 166-169.)

Niin sodan aikana kuin sodan jälkeen parodinen huumori ja rennot aiheet, muun muassa jermukuvaukset, jäivät usein sensuurin seulaan tai julkaistiin jonkinasteisen siistimisen jälkeen. Helena Pilkkeen mukaan (2009, 184, 229, 247-248, 276) huumori oli käsiteltävistä aiheista kaikkein vaikein sensuuriviranomaisille. Ekholm (2000, 129, 132) mainitsee populaarin "matalaviihteen" olleen myös valvontakomission silmätikkuna. Sensuuri ilmeisesti vaikutti suoraan sota-aiheisten kirjojen julkaisuun ja saatavuuteen, ja se on saattanut myös välillisesti vaikuttaa sota-aiheen niukkaan käsittelyyn parodian keinoin. Kun huumoria ja monitulkintaisuutta on pidetty useasta syystä (mm. poliittisista, uskonnollisista, siveellisistä tai kirjallisista syistä; ks. Pilke 2009, 229 ja Ekholm 2000, 132) arveluttavana, on ymmärrettävää, että harva kirjailija on valinnut sen pääsääntöiseksi esitystavakseen. Parodisen kerronnan elinvoimasta kertoo kuitenkin se, että sitä selvästi löytyy monesta kotimaisen sotakirjallisuuden klassikosta. Päivälehtien Marsipansoldaten-kritiikeissä on kaikuja "virallisen" linjan normittavasta asenteesta, jonka mukaan huumori ja ironia ei ole sovelias tapa kuvata sotaa (esim. Bjon 15.11.2001; Karonen 14.11.2011; Korsström 16.9.2001; Lassila 14.11.2001; Mäkelä 11.11.2001), olkoonkin, että joissakin arvosteluissa arvosteltiin myös tätä asennetta (esim. Kurikka 5.12.2001). 
Sodasta kirjoitetaan 2000-luvulla aikaisempaa useammasta näkökulmasta ja siitä ymmärrettävästi kirjoittavat myös muut kuin sodassa taistelutilanteessa olleet ihmiset (Nykänen 1.12.2002). Sotaa on muisteltu ja tutkittu uudella tavalla myös historiatieteissä. Niin kutsuttu uusi sotahistoria on nostanut esiin aiemmin vaiettuja asioita kun historiantutkimus itsessään on muuttunut yksiäänisestä moniääniseksi ja osin yksilökeskeisemmäksi yhden kansakuntakertomuksen tuottamisen sijaan. Sodan myyttiä purkavalla, uudella sotahistorialla on näin myös yhteytensä kirjallisuudentutkimukseen ja sen tutkimusmetodeihin. Olennaista ei ole ainoastaan se, mitä tapahtui, vaan myös se, kuinka tapahtunut kuviteltiin (Bourke 2006, 32). Toisen maailmansodan kuvauksessa Suomessa uusiksi aiheiksi ovat nousseet muun muassa lapset ja nuoret sodassa, suomalaisten ja saksalaisten sotilaiden lapset, sotakokemuksen muistelu ja trauman purku, suomalaisten keskitysleirit Itä-Karjalassa sekä saksalaisten sotilaiden mukana Suomesta lähteneet naiset (Siltala 2006, 53; Lahtonen 2011, 25-26). Historiantutkimuksessa myyttiä puretaan nostamalla keskiöön sodan vaikutus siviileihin ja siten muistuttamalla sodan koko yhteiskuntaa läpäisevästä vaikutuksesta. Fiktiossa myyttiä puretaan Marsipansoldatenin tavoin laventamalla sotaromaanin lajia kirjoittamalla taistelu- ja kotirintamakokemukset, sotilas- ja siviilikokemukset, limittäen ja sivumäärältään suhteellisen tasapuolisesti samaan teokseen. Marsipansoldatenissa tämä rinnastaminen tapahtuu alleviivatusti myös päähenkilöiden, Frejn ja Göranin kautta. Sotilainakin molemmat ovat tietoisia siviiliydestään ja ovat jopa ajoittain huolissaan, että siviilielämän tavat unohtuvat armeijassa.

\section{Dokumentaarisuus sotaromaanissa}

Marsipansoldatenin saama kritiikki oli kaksijakoista. Yhtältä arvioissa näkyy perinteiseksi mielletty kotimainen sotakirjallisuus, jossa suositaan arkkityyppejä ja joka on dokumentaarista ja omakohtaista tai tietoon nojaavaa, ja jonka parhaana esimerkkinä pidetään usein Väinö Linnan teosta Tuntematon sotilas. Toisaalta arvioissa on myös tunnistettu hajanaisuuden kautta totuudellisuuteen pyrkivä fiktio. Voidaan kysyä, miksi puolidokumentaarisuus sitten on yleensä vakiintunut suomalaisen sotakuvauksen normiksi. Onko niin, että aika ei ole vieläkään kypsä sosiaalista todellisuutta toisella tapaa representoivalle suomalaiselle sotafiktiolle, vaikka se on ollut ja on mahdollista muualla, esimerkiksi saksalaisessa ja amerikkalaisessa sotakirjallisuudessa? ${ }^{3}$

Dokumentarismi sotakirjallisuuden tyyppinä on Niemen $(1988,162)$ mukaan tullut Suomeen 1960-luvulla amerikkalaisen tutkivan journalismin ja saksalaisen draaman kautta. Clas Zilliacus $(1999,217)$ katsoo dokumentarismin rinnastuvan ilmiönä tunnustuskirjallisuuteen, raporttiin ja kollaasiin, jotka teksteinä pyrkivät aitouteen ja irtisanoutuvat kuvitellusta. Zilliacus kuitenkin toteaa, että "[dokumentaarikirjallisuuden] aineisto siirrettynä todellisuuden piiristä taiteen piiriin avartui sisällöltään [--].” 
(Zilliacus 1999, 219.) Dokumentaarisuutta on siis vaikea rajata, onhan omakohtaisen kokemuksen ja sen dokumentoinnista ja käytöstä fiktion materiaalina puhuttu myös toisin: muun muassa Pertti Lassila mainitsee, että rintamakokemus oli sotaa käsittelevän kaunokirjallisuuden kirjoittajista Yrjö Jylhälle "voima ja taakka" ja että sota oli ylipäänsä "vaikea käsiteltävä" sota-ajan kirjailijoille (Lassila 1998, 9). Vesa Karonen (9.11.2003) esittää totuudenmukaisuuden sotakerronnan ehtona syntyneen heti talvisodan jälkeen järjestettyjen kirjoituskilpailujen aikaan ja vahvistuneen 1950- ja 1960-luvuilla modernististen sotaromaanien julkaisun myötä. Helena Pilke (2009, 143-144, 147, 151-153) katsoo autenttisuuden ehdon olleen sota-aikana niin kriitikoiden, kirjailijoiden kuin kustantajien ylläpitämä; kustantajien näkökulmasta autenttisuus oli myös tärkeä myyntivaltti. Aikalaislukijatkaan eivät olleet vaiti; Pilkkeen mukaan yleisö kävi puolestaan välillä kiivastakin lehtikeskustelua julkaistujen kertomusten aitoudesta. Myös kohua aiheuttaneen Paavo Rintalan Sissiluutnantin (1963) puutteiden on väitetty johtuneen toisen käden tietoihin tukeutumisesta (Niemi 1988, 155), vaikka kohussa oli pohjimmiltaan kyse kertojan ja tekijän väärästä samastamisesta (Salin 2007, 20).

Dokumentarismissa tavoitellaan yksityistä kokemusta ja nostetaan subjektiivisuus virallisen totuuden rinnalle. Dokumentaristi pohjaa työnsä autenttisiin kertomuksiin ja yhdistelee tietojaan juonelliseksi kokonaisuudeksi. Dokumentaarisen sotaproosan kirjoittaja voi olla joko rintamakokemusta omaava, sodan omakohtaisesti aikuisiällä kokenut mies (Karonen 9.11.2003) tai arkistolähteisiin, haastatteluihin, kirjeisiin ja päiväkirjoihin tekstinsä perustava henkilö, joka on kokenut sodan joko lapsena tai edustaa kokonaan myöhempää sukupolvea (Nykänen 1.12.2002). Tosin yhtenä tärkeänä autenttisena tekstinä pidetyn muistelmateoksen Kollaa kestää kirjoittaja Erkki Palolampi $(1940,5)$ toteaa teoksen esipuheessa, että kirja perustuu "lyhyihin merkintöihin [--], joita on täytynyt muistin varasta täydentää." Palolampi jatkaa: ”Useassa seikassa, etenkin päivämäärissä ja luvuissa, olen saattanut erehtyä" (mt. 5). Myös Kollaa kestää -teoksen autenttisuudesta kiisteltiin heti teoksen ilmestyttyä (Pilke 2009, 144145); tässä mielessä autenttisuus-dokumentaarisuus-fiktio-debatti on ollut kiinteä osa kotimaista sotakirjallisuuden kontekstia jo varhain. Autenttisuutta pidettiin tärkeänä, mutta yhtenäistä määritelmää tai muuta taetta sille ei esitetty kuin kirjoittajan omakohtainen taistelukokemus. Sotakuvaus siis rajautui heti 1940-luvun alussa nimenomaan taistelun kuvaukseksi.

Kun sotaa on yhtäältä pidetty vaikeana aiheena ja toisaalta sen parhaiksi kuvauksiksi nostetaan fiktiivisyydestään ja alleviivatusta tarinallisuudestaan tunnetut Väinö Linnan (Tuntematon sotilas, ja siinä esim. Honkajoen hahmo) ja Veijo Meren (Sujut, Manillaköysi) teokset sekä Palolammen tekstin kaltaiset autenttiset mutta muistinvaraiset ja episodimaiset kertomukset, voidaan todeta, että dokumentarismiin usein liitettävä autenttisuus ei ehkä olekaan niin vahva piirre suomalaisessa sotakirjallisuudessa kuin on ajateltu. Pyrkimys fiktion dokumentaarisuuteen voi myös olla juuri ainoas- 
taan hajanaisia narratiiveja tarjoavan tosipohjaisen aineiston synnyttämää: on tavallaan arkijärjen mukaista olettaa, että kun faktaa on tarpeeksi, aineisto saturoituu ja syntyy yksiselitteinen narratiivi. Kun näin ei odotuksenvastaisesti kuitenkaan käy, fiktio paradoksaalisesti tarjoaa riittävän tilan, jossa välittää ajan tunnelmaa ja henkilökohtaisia kokemuksia mahdollisimman autenttisen tuntuisesti ja johdonmukaisesti. Ne tapahtumat ja tilanteet, joista ei ole varmuutta, voidaan kuvitella (Niemi 1988, 16). Tätä tulkintaa tukee myös Niemen $(1988,164)$ dokumentaarisuuteen liittämä yksityinen kokemus ja subjektiivisuus.

Lundbergin teosta voidaan pitää dokumentaarisena ja osin autenttisena, sillä sen aineisto pohjaa tekijän isän ja setien sodanaikaiseen kirjeenvaihtoon (Korsström 16.9.2011). Myös Lundbergin aiemmissa teoksissa esiintyvä Leonardin hahmo perustuu kirjailijan isänisään (Tybjerg 1996). Kirjeitä ja muita mahdollisia aineistoja ei kuitenkaan eksplikoida itse teoksessa lähteinä tai innoittajina.

\section{Groteski sotaromaanin ironian keinona}

Marsipansoldatenin kerronnan ironia on moninkertaista: osin se toistaa kotimaisessa sotafiktiossa jo aiemmin nähtyä ja sen kiinteäksi piirteeksi miellettyä vastakkainasettelua virallisen ja "todellisen" sodan välillä, osin se on Linda Hutcheonin tutkiman, niin kutsutun historiografisen metafiktion keskeinen kerronnan tapa (Hutcheon 1988, 124-125). Mika Hallila on katsauksessaan metafiktion käsitteeseen todennut, että metafiktioksi on luettu sekä parodisia että keinovalikoimastaan tietoisia, kirjalliset keinot ja konventiot tunnistavia tekstejä, jotta teksti voi niitä produktiivisesti käyttää (Hallila 2001, 122-123). Marsipansoldatenissa on historiografisen metafiktion piirteitä, mutta sen nimeäminen metafiktioksi ei ole täysin yksiselitteistä. Metafiktiivisyys ei ole juurikaan ollut kotimaisen sotaromaanin vallitseva piirre. Kuitenkin Marsipansoldaten vei ilmestyessään moniäänisyydellään ja yksityistä ja julkista puhetta ja kokemusta limittäen tässä mielessä lajia uuteen suuntaan, mikä on ansio.

Hutcheonin mukaan ironia on tyypillinen historiografisen metafiktion ilmaisun tapa, koska se on ainoa keino sekä paikantaa teksti kaanoniin että kapinoida kaanonia vastaan (Hutcheon 1988, 130). Vakavaksi aiottu ironinen parodia on tavallaan ainoa mahdollinen tapa kirjoittaa metafiktiota: vain tällöin voidaan olematta naiivi tunnustaa sekä historiallisten tapahtumien faktuaalisuus - siltä osin kuin se on mahdollista todeta ja todentaa - että historian ja kirjallisuuden tekstuaalinen luonne, niiden nojautuminen kertomuksiin (mt. 124).

Sotaromaanissa ironian käytetyin esittämisen tapa on groteski (Niemi 1988, 150154). Toisteisen groteskin avulla syntyy osa tekstiin rakentuneesta ironiasta, mikä kytkee teoksen myös postmodernistiseen romaaniin. Tässä tarkoituksessa ironia merkitsee samanaikaista eroa ja kytköstä menneeseen (vrt. Hutcheon 1988, 125), mikä sopii myös historialliseen sotaromaaniin. 
Ironia liittyy sotafiktioiden pyrkimykseen jäsentää sodan kaoottista puolta, mikä usein tapahtuu groteskin keinoin. Kahden vastakkaisen asian kytkeminen yhteen tai inkongruentti yhdistely on yksi kirjallisen groteskin tunnus (Hosiaisluoma 2003, 286; Perttula 2010, 17). Yletön liioittelu on myös Mihail Bahtinin $(1995,270)$ mukaan yksi groteskin tyylin tunnusmerkeistä. Irma Perttulan (2010, 22, 32) mukaan groteskille on tyypillistä normin rikkomus, sopivaisuuden ja niin sanottu hyvän maun ylitys. Normin rikkomuksena groteski käsittelee viettien ja ruumiintoimintojen (mm. seksin ja ruoan) sääntelyä ja niihin liittyvää koettua häpeää (mt. 55). Inkongruentti yhdistely voi olla esimerkiksi inhimillisen ja eläimellisen yhdistämistä, inhimillisen ja esineellisen yhdistämistä, muodonmuutos (esim. ihmisestä eläimeksi tai päinvastoin) tai esitystasojen inkongruenssia, esimerkiksi traagisen ja koomisen yhdistelyä tai diskurssin ja tarinan yhteensopimattomuutta (mt. 64, 68, 78-86).

Näen groteskin yhtenä ironisen sotakuvauksen tunnusomaisimmista piirteistä. Niemen $(1988,150-151)$ mukaan groteski liittyy kotimaisessa sotafiktiossa erityisesti modernistisiin jatkosotakuvauksiin. Se on voimallisimmillaan kontrastina, jyrkkänä rinnastuksena; jatkosodan kohdalla rinnastus on syntynyt juuri koetun sodan sekä puhutun ja julkaistun virallisen eetoksen mukaisen sodan ristiriidasta, jonka esimerkkinä Niemi käyttää Veijo Meren Sujuja (mt. 154). Groteskin jyrkkä rinnastus on kiinteästi läsnä sodassa samanaikaisena yksityisenä ja kollektiivisena kokemuksena, jotka harvoin kohtaavat tai lankeavat yhteen. Useissa suomalaisissa sotaklassikoissa korostuu yksittäisen kansalais- tai siviilisotilaan neuvokkuus ja pienryhmän arkisesti jäsentynyt toiminta, mikä asettuu usein myös ristiriitaan säännellyn armeijakäytöksen ja suuren kansakuntanarratiivin kanssa. Voidaan ajatella, että ironia ja groteski ovat keskeisiä ellei jopa keskeisimpiä suomalaisen sotafiktion esittämistapoja, joiden ohi myös on katsottu ensisijaistaen julkisen eetoksen isänmaallis-uskonnollista kansakuntanarratiivia.

Groteskeja kuvia on nähty aiemminkin suomalaisessa sotaromaanissa, esimerkiksi Veijo Meren Manillaköydessä, Jorma Korpelan Kenttävartiossa ja useammassa (esim. Kenttä ja kasarmi, Vääpeli Sadon tapaus, Yhdeksän miehen saappaat) Pentti Haanpään teoksessa (vrt. Perttula 2010, 58; Salin 2002, 236-240). Ne ovat siis suomalaisen sotaromaanin genrelle ominaisia ja liittyvät usein henkilöhahmon vierauden ja absurdin kokemukseen.

Ilona Kemppainen ja Ulla-Maija Peltonen korostavat sankaruuteen liittyvää emotionaalista investointia, yhteisön jäsenten halua kokea sankarin hahmon ja artikuloidun sankaruuden kautta kollektiivisia tunteita. Kollektiiviset tunneilmaukset esitetään rituaaleina ja tunneilmaus on niissä sujuvasti läsnä poliittisen ja nationalistisen sisällön rinnalla. (Kemppainen \& Peltonen 2010, 14-15). Koska ironiaan sisältyy Hutcheonin $(1994,47,177)$ mukaan aina affekti, tunnekokemus, voidaan olettaa, että sotasankaruutta ironisesti esitettäessä ollaan moninkertaisesti intensiivisen tunnekokemuksen äärellä: innostumme sankarista, nauramme hänelle, suremme hänen 
vajavaisuuksiaan, häpeämme häntä, iloitsemme ja olemme ylpeitä sankarin saavutuksista ja koemme ironian mahdollistamana kaikkia näitä tunteita yhtä aikaa. Kun ajatellaan sankarin olevan viime kädessä yhteisön palveluksessa, tunnekokemus suuntautuu meihin yhteisönä. Ironia siis mahdollistaa yhteisöllisten käsitysten samanaikaisen rikkomisen ja vahvistamisen. Marsipansoldatenia lukiessa rikomme ja vahvistamme käsityksiämme suomalaisen nykyhistorian yhdestä käännekohdasta, toisesta maailmansodasta sekä käymme tekijän mahdollistamana keskustelua siitä, miten sodasta nopeana yhteiskuntamullistuksena on aiemmin kerrottu ja voi nyt kertoa.

\section{Ruoan groteski ja kytkös nuoruuteen}

Marsipansoldatenin monisyisen ironian hallitsevin esittämisen tapa on groteski. Groteskit kuvat liittyvät Marsipansoldatenissa usein ruokakuvaukseen, missä ne ovat kaikkein ilmeisimpiä useudellaan ja yksityiskohtaisuudellaan, mutta groteskeja piirteitä liitetään teoksessa myös sodankäyntiin, kuolemaan ja Göranin sukupuolisuhteisiin. Groteskit kuvat kertovat myös Marsipansoldatenin hahmojen subjektiivisista kokemuksista sota-arjessa. Niissä ollaan kuin pois paikoiltaan, kokemus on usein väärä tai vino. Se, kenen näkökulmasta kuvattu kokemus on väärä tai vieras, vaihtelee: kyse voi olla hahmon kokemuksesta suhteessa tilanteessa kuvattuun toimintaan, kertojan ja hahmon ristiriitaisista asenteista tai viime kädessä lukijan kokemasta tyrmistyksestä.

Marsipansoldatenin lehtiarvioissa ihmeteltiin teoksen yltäkylläistä ruokakuvausta toiminnallisen sotakuvauksen kustannuksella (vrt. Mäkelä 11.11.2001). Ruoan runsaat kuvat ovat paradoksaalisessa suhteessa myös teoksen kuvaamaan historialliseen aikaan, jolle oli leimallista niukkuus ja puute. Puutteen ja yltäkylläisyyden välinen kontrasti toimii siis groteskin tunnusmerkkinä. Kuitenkaan tämäkään kontrasti, niin kuin teoksessa esiintyvät muut rinnastukset, ei ole yksiselitteinen tai selkeä.

Ruoka oli sota-aikana keskeistä myös myönteisenä ja mielialaa kohottavana arjen ilona. Esimerkiksi Kyllikki Villan mukaan jatkosodan aikana rintamalla olisi ollut jatkuva nälkä ilman kotoa lähetettyjä paketteja. Niiden odottaminen ja niistä löytyvien herkkujen yhteinen jakaminen loi myös sosiaalista koheesiota rintaman arkeen (vrt. Lappalainen 2006, 134). Ruoasta puhuttiin paljon. Villa nimeää äitien tarjoaman ruoka- ja varustehuollon "huomionarvoiseksi tueksi Suomen armeijalle". (Villa 2006, 13.) Myös Erkki Palolampi kirjoittaa värikkäästi sodan välittömäksi lähikuvaksi luettavassa Kollaa kestää-muistelmateoksessa ruoan keskeisyydestä rintamalla, ”pikku kesteistä" ja taitavista kokeista, jotka loihtivat kotiväen pakettien antimista herkullisia nautintoja koko rykmentille (Palolampi 1940, 181; 177-188). Marsipansoldatenin ruokakuvaus on siis varsin autenttista kun se kuvaa yksityiskohtaisia pyyntöjä ja ruoan syömiseen liittyvää iloa ja mielihyvää. Ruoka myös muistuttaa konkreettisesti kodista ja huolenpidosta. 
Ruoan groteski on ensisijaisesti liioittelua ja yltäkylläisyyttä, ja se viittaa tekstuaalisesti myös lasten- ja seikkailukirjoihin. Wendy R. Katzin (1980, 193) mukaan lastenkirjoissa päähenkilön asenne ruokaan sekä ruokailu- ja käytöstavat kertovat tunne-elämän tasapainosta ja päähenkilön mukautumisesta sosiaaliseen järjestykseen. Päivi Lappalainen muistuttaa ruoan ambivalenssista lasten- ja nuortenkirjoissa. Ruokaan liittyy yhtäältä usein lastenkirjojen koomisen asenteen (ks. Katz 1980, 199) vuoksi myönteisiksi ja iloisiksi tulkittavat, anarkistiset ja hillittömät runsauden kuvaukset, toisaalta ruoan synkemmäksi katsottava funktio vallankäytön välineenä ja lasten ja aikuisten välisten valtasuhteiden ilmentäjänä. (Lappalainen 2006, 127.) Ruoka toimii myös hoivan ja perusturvan symbolina, äiti-lapsi-suhteen tärkeimpänä merkkinä (Lappalainen 2006, 129).

Martha-äiti on Lundbergin teoksessa ensisijainen herkkujen lähettäjä, ja hän tekee kaikkensa täyttääkseen Göranin pyynnöt:

Breven hem handlar om vad han behöver: smör som är bra för ögonen, vitt bröd som är bra för magen, bullar, skorpor, kex, ost, inlagd sill, ättiksgurkor och annat salt och gott, dessutom något sött, sylt, karameller, pastiller. Te och kakao. (M 90.)

Martha onnistuu ruokalähetyksillään ylläpitämään Göranin mielikuvaa kodista, jossa kaikki on hyvin. Vaikka Göranin pyynnöt ovat ajoittain kohtuuttomia ja jopa mahdottomia toteuttaa, Martha ei koskaan suoraan kiellä tältä mitään. Myös äidin roolin ottava armeija pitää huolta vatsallaan marssivasta Göranista:

Så maten är inte så pjåkig. 40 gram socker och 40 gram smör om dagen, fyra kakor Vasa knäckebröd, ost eller marmelad tre gånger i veckan, dessutom grahammjöl och lard så man kan steka plättar på kvällarna. Ur fältköken vankas det gröt på förmiddagen och makaronisoppa eller ärtsoppa på eftermiddagen. Köttkonserver och potatis besorgar de själva i någon kolchos. (M 178.)

Ruoka on teoksen selvä johtomotiivi toistuvuutensa vuoksi. Sillä on useita tehtäviä: se korostaa ruumista kaiken elämän konkreettisena tyyssijana, ilmentää Göranin ambivalenttia ja päättymätöntä äitisuhdetta ja toimii vastapainona sodan abstraktille ylevyydelle muistuttaessaan sodan arkisesta ja yksityisestä puolesta. Ruoka korostaa siviiliyttä ja yhteisöön kuulumista (Katz 1980, 193; Keeling ja Pollard 2009, 10-11). Sotakirjan motiiviksi kirjoitettuna ruoka voidaan nähdä voimakkaana metaforana eloonjäämisestä ja siviiliyhteisöstä, joka on aina sodan tilapäistä ja poikkeuksellista kaaosta vahvempi ja kestävämpi.

Nuortenkirjoihin viittaava, ruokaan liittyvä vallankäyttö kääntyy teoksessa päälaelleen. Kun tavanomaisessa nuortenkirjassa aikuiset, usein ruokkivat äidit, käyttävät ruoan avulla valtaa suhteessa lapseen, on se Marsipansoldatenissa Göranin keino osoittaa omaa ylempää sotilaan paikkaansa suhteessa kotiin. Göran on häikäilemätön ja kohtuuton pyynnöissään. Kotirintaman pula ei konkretisoidu hänelle 
ja lisäksi hän katsoo Kummelien perhehierarkiassa olevansa ensisijainen suhteessa muihin sisaruksiin. Nurinkääntö on teoksessa kritiikin väline. Sotilas ei ole automaattisesti ihailtava tai hyveellinen, ennemminkin kartettava. Toisaalta Marthan hoiva ja Göranin päättymättömät pyynnöt näyttävät kotirintaman niukan liikkumavaran sellaisessa ideologisessa ilmapiirissä, joka automatisoi sotilaan edun koko kollektiivin eduksi. Nurinkääntö kytkeytyy myös tekstuaalisena keinona groteskiin.

Martha näkee runsaasti vaivaa ruokkiakseen suosikkinsa, mutta pyrkii myös olemaan tasapuolinen herkkulähetyksissään molempien sotilaspoikiensa suhteen. Sotilaan toiveiden toteuttaminen on myös ensisijaista isänmaallisen puheen hierarkiassa. Petter ojentaa Görania ahneudesta, Frej puolestaan tahollaan ymmärtää, että ruoka lohduttaa:

All denna brist gör att Frej har börjat förstå Jösses omaskerade tiggande. När han har avnjutit tomaterna och skorporna och moster Alfhilds Sverigekaffe vill han ha mera tomater och skorpor och Sverigekaffe fast han har föresatt sig att aldrig. Allt går så mycket lättare om man har något gott att se fram mot. (M 171.)

Martha hoivaa Görania enemmän kuin Frejtä, mikä korostaa sitä, että Göran ei irtaudu äidistään, toisin kuin Frej. Göranin lapsen rooli säilyy koko teoksen ajan. Teoksen loppuvaiheissa Frej omaksuu Göranin hahmosta tutuksi tulleen puheen kuvitellusta ruoasta, jopa liioitellummin kuin mihin Göran koskaan pystyy:

För Marja berättar han om Simons mosters åttioårsdag [--]. ”Det hade lönat sig att vara med på det kalaset", försäkrar han. Och berättar om kalvsteken med gräddsås, om glassmaskinen som är den enda i Granboda, om orgierna av krusor, kransar och spritsar, bullarna bakade med smör och ägg, den tjocka grädden man stjälper i äkta kaffe, smörgåsarna stora som dasslock dignande av skinka och ost som bärs in till kvällsteet. Gästerna sitter i salen på sjunde timmen, dästa som gökungar oförmögna att spränga holken och ta sig ut. (M 404-405.)

Göranin hahmossa esitetty viettien karnevaali siis jatkuu Frejn puheissa. Frejn suhteellisen normaali asenne ruokaan muuttuu kirjan lopulla göranmaisen ahneeksi ja liioittelevaksi. Tämä voidaan tulkita merkiksi kasvavasta turhautumisesta ja neuvottomuudesta sodan loppuessa, jolloin sotaan tottuneen Frejn tunne-elämä järkkyy (vrt. Katz 1980, 193). Seksiin viittaavat pikkuleipäorgiat, tarpeillakäymiseen liittyvät vessankannen kokoiset voileivät, ylensyönnistä räjähtävät vieraat ja pakotettua hoivaa nauttivat ahnaat käenpojat vahvistavat kielikuvina sitä, että osa Göranin hahmossa kuvatusta äärimmäisyydestä on siirtynyt veljeen. Frej ikään kuin taantuu, mikä alleviivaa sodan loppumisen ristiriitaista tragiikkaa ja siviiliin paluun lähes ylipääsemätöntä vaikeutta: Frejllä ei ole pikkupojan ymmärrystä kummoisempia valmiuksia elää rauhan ajan yhteiskunnassa, sodassa saadusta elämänkokemuksesta ei ole hyötyä ja tämän hän ilmeisimmin itsekin ymmärtää (vrt. Kirves 2008, 390). 
Romaanissa sotilaat eivät näe nälkää samalla tavoin kuin siviilit. Vaikka armeijan muonituksen taso vaihteleekin, Frej ja Göran eivät koe samaa puutetta kuin kotiväki. Lisäksi armeijan liikkuessa sotilaat "besorgaavat" (vrt. Näre 2008, 348), ottavat omin luvin itselleen ruokatarpeita ja muutakin irtaimistoa tyhjistä asuintaloista, kaupoista ja kolhooseilta.

Från mamma kommer det både skorpor och karameller som ger Frej ett styng av ont samvete. I Hemfinland är mjölbristen skriande, medan de själva har besorgat en stor säck. Jäst har en permittent haft med sig i stora mängder, och i plutonen finns det en konditor som bakar prima bröd i skolköket i en rysskola. "Ni behöver mjölet själva", skriver han, och beskriver sitt nuvarande liv som prinsens i bagarboden. (M 194.)

Miksi runsasta ruokakuvausta sitten pidettiin sopimattomana normin ylityksenä lehtiarvosteluissa, jos ruoasta puhuminen, sen jakaminen ja siitä iloitseminen on ollut sota-ajalle tyypillinen kirjeiden ja keskustelun aihe ja siten tulkittavissa Marsipansoldatenin kohdalla sotaromaanin lajin ehdon täyttäväksi autenttisuudeksi? Ruoka ei yksityisen ja arkisen hoivan ja ruumiin korostajana sovi julkiseen, isänmaallisen ideologian värittämään ja henkisyyttä korostavaan narratiiviin sodasta kansakunnan historian suurena hetkenä. Henrik Meinanderin mukaan tämä narratiivi on säilynyt suhteellisen yhdenmukaisena jatkosodan päättymisestä aina 1990-luvulle asti. Kun sodan muistot moninaistuvat ja moniäänistyvät, sodan nykyinen totaalinarratiivi hajoaa toisistaan riippumattomiksi osatulkinnoiksi. (Meinander 2009, 397.) Marsipaanisotilaan vastaanotto kuitenkin osoittaa, että romaania luettiin enimmäkseen isänmaallisen ideologian kontekstissa, johon ruoka ja varsinkaan sen runsas ja yksityiskohtainen kuvaaminen ei yksityis-ruumiillisena motiivina sovi.

Kun Marsipansoldatenia vertaa esimerkiksi Palolammen ja Villan autenttisiksi luokiteltaviin kuvauksiin sodasta, nousee kaikista hyvin selvästi esiin ihmisten kyky elää ja toimia rinnakkaisissa todellisuuksissa, yhtäältä isänmaa- ja uhridiskurssissa ja toisaalta ruokaa, sanaleikkejä ja muuta yhteishenkeä huumorin, ilon ja nuoruuden keinoin nostattavassa epävirallisessa yksityisen diskurssissa. Meinanderin tarkoittamat osatulkinnat eivät ehkä tässä mielessä ole olemukseltaan uusia, vaan unohdettuja ja ensisijaiseksi katsotun isänmaallisen totaalinarratiivin varjossa olleita. Marsipansoldaten on juuri paradoksaalisesti yksityiskohtiin keskittyessään varsin kokonainen kuva sodasta, eikä ainoastaan yksityistä sotakokemusta osatulkinnaksi mieltäen alleviivaava. Siinä armeijan, valtion, kyläyhteisön, koulun ja perheen instituutiot, joilla totaalinarratiivia rakennetaan, nähdään nimenomaan joukkona yksilöitä ja heidän kokemuksiaan.

Sodankäynnin groteski liittyy ruoan lisäksi myös muuhun materiaan, esimerkiksi vaatteisiin, sotilaiden itselleen ottamiin matkamuistoihin ja Frejn kanoottiin, jonka rakennustarpeet Petter vaivoin haalii kokoon ja jonka Frej myöhemmin huolettomasti hylkää. Göran lihoo armeijassa ja sodan kestäessä: 
Inget under att byxorna hemifrån är för små: 12 kilo har Göran gått upp sedan han inkallades. Det är ett konststycke i en tid då hela Finland magrar [--]. (M 114.)

Eftersom Göran i en mening skriver att han mår som en prins och har gått upp flera kilo och i den följande tigger mat som en gökunge, utgår han, Petter, ifrån att Göran knappast lider någon verklig nöd. Har han över huvud taget reflekterat över hur hemfolket har det? Inser han att deras ransoner är knappare än i fält? Har han någonsin tänkt på hur mor sliter och släpar och försakar och inte unnar sig maten så att han, Göran, ska få sina paket fullastade med läckerheter [--]? (M 157.)

Göranin lihomisessa on myös groteskille tyypillinen jyrkkä mittakaavan rinnastus: Göran yksin lihoo, kun koko muu maa laihtuu. Göranin lihominen voidaan tulkita myös symboliksi siitä, että sodan kestäessä Göranin yksityinen sotakokemus erkaantuu yhä enemmän virallisesta ja toisteisesti kerrotusta sotakokemuksesta. Göranille sota näyttäytyy materiaalisesti hyvin toisenlaisena kuin muille rintamamiehille saati kotiväelle. Sodassa Göranin hyvinvoiva ruumis voidaan nähdä myös vertauskuvana siitä hyödystä, jota sodan poikkeustila markkinoiden muuttuessa tuottaa joillekin: sotatarvikkeiden valmistajille, välittäjille ja trokareille.

Göranin lihominen tekee hänestä myös korostetusti antisankarin. Jean Webbin mukaan syövä ja lihava poika on ollut välttämätön vastapari korostamaan nuortenkirjojen varsinaisten poikasankarien myönteisiä ominaisuuksia (Webb 2009, 120). Seikkailu- ja nuortenkirjat toimivat koko teoksen yhtenä intertekstinä, mikä myös arvioissa osittain tunnistettiin. Yksi seikkailu- ja nuortenkirjojen pedagoginen tehtävä on ollut ehdollistaa poikia hyveellisen sotilaan rooliin (Dawson 1994, 146-147; Kemppainen 2006, 229). Webbin analyysissa perinteisen maskuliinisen sankarin kristillis-nationalistiseen arvojärjestelmään pohjaava moraalinen ylemmyys näkyy atleettisena ruumina (Webb 2009, 107). Göranin hahmon moraalinen kyseenalaisuus näkyy siis ruumiissa. Näin hahmon antisankaruus korostuu ja kytkeytyy samalla isänmaalliseen diskurssiin. Kun Göran toisaalta pystyy myös hyviin tekoihin, hahmon antisankaruus hämärtyy ja sankaruuden ambivalenssi jä päällimmäiseksi.

Päähenkilöiden nuoruutta ja protosotilaan ambivalenttia miehekkyyden ja nuoruuden yhdistelmää käsitellään teoksessa varsin terävästi (vrt. Tepora 2007, 296, 301). Esimerkiksi käydessään aliupseerikoulua Riihimäellä Göran osallistuu usein airuena hautajaisiin:

Man kan inte låta bli att bli en gnutta smickrad över att anses värd att visas upp vid solenna tillfällen. Tvagen som han blivit lärd av mor, rakad och borstad, uppstassad och rörande ung, förhöjer Göran stämningen i kyrkan. Blickstilla, eller nästan, står han med blicken framåtriktad, men dragen är mjuka och gossen i uniform så söt som vore han gjord av marsipan. Han är inte på något sätt omedveten om att Riihimäkis fruar och fröknar gärna tittar på honom. Förstulet eller så gott som direkt, och det behöver man inte skäm- 
mas för. Hedersvakten står som en sinnebild för dem man sörjer: unga, unga män med mjuka drag och levande blå ögon, fallna för fosterlandet i sin första blomning. (M 55.)

Katkelmassa sotilas redusoituu pelkäksi kuvaksi tai symboliksi väkivaltaisen kuoleman kokeneen nimettömän sotilaan hautajaisissa, mitä myös Göranin pinnallinen ilo esilläolosta korostaa. Hautajaiset ja Göranin rooli niissä airuena toistuvat Göranin palvelusaikana monta kertaa. Kontrasti sodassa vammoihinsa kuolleen vainajan tuhoutuneen ruumiin ja sievän kunniavahdin pehmeiden piirteiden välillä on selvä. Sotaan lähtevät ja siellä kuolevat ovat käytännössä lapsia.

Myös romaanin nimi on itsessään kontrasti: pehmeä ja makea kakunkoristeen materiaali ja ulkomainen herkku yhdistettynä kovaksi miellettävään sotilaaseen. Nimeä voi pitää groteskille tyypillisenä arvonalentamisena ja Göranin hahmon perimmäisen epätasapainon merkkinä. Manteliin ja sokeriin yhdistyy mielikuva yltäkylläisyydestä ja Göranin hillittömästä persoudesta kaikille herkuille. Oraalinen nautinto ikään kuin asettuu tappamista ja maskuliinisuutta vastaan. Tekstissä myös toistuu sanonta "prinssistä paakarinpuodissa” kun kuvataan Frejn ja Göranin sotaa ruoan avulla (M 157, M 194). Marsipaanin ja sotilaan yhdistelmää on pidetty myös suomenruotsalaisuuden ironisointina (Kurikka 5.12.2001). ${ }^{4}$

\section{Lopuksi}

Marsipansoldaten on osoitus siitä, että sotaa voidaan traagisesta pohjavireestä huolimatta kuvata perheen kautta myös ironisesti ja lämpimästi. Romaani kritisoi yksioikoista hegemonista asennetta sodan perintöön, ja on itsessään todiste moniäänisestä, mutta koherentista sotakuvauksesta. Marsipansoldaten nostaa yksityisen sotakokemuksen kansakuntanarratiivin rinnalle, ja tekee sen hienovaraisesti, mutta kriittisesti.

Ruoan lisäksi teoksessa on muitakin motiiveja, esimerkiksi toistuvat kirjeet ja muu ihmissuhteisiin suuntautuva toiminta, jotka rakentavat teoksen yksityis-epävirallista diskurssia julkisen uskonnollis-nationalistisen diskurssin vastinpariksi. Ruoka on kuitenkin motiiveista keskeisin ja sillä on teoksessa useita tehtäviä. Ruokakuvaus kytkeytyy yhtäältä perinteisiä uskonnollis-nationalistisia sankarikuvia tehokkaasti rakentavaan nuorten seikkailukirjagenreen. Se korostaa sodan toimijoiden nuoruutta ja lapsuuden läheisyyttä. Lisäksi se viittaa sotaan korostetun materiaalisena toimintana, niin tuhona kuin julmana kilpailuna resursseista ja elämisen edellytyksistä, joista ruoka on perustavin.

Voimakkaimmin ruoka toimii teoksessa vahvan ja eloonjäävän siviiliyhteisön metaforana ja alleviivaa sotaa poikkeustilana, joka on tilapäinen ja jonka siviiliyhteisö viime kädessä selättää. Tässä mielessä teos edistää sotaromaanin lajin pysyvintä tehtävää, rauhan ja rauhassa elävien yhteiskuntien puolesta puhumista ja pasifismia, mikä 
esteettisesti korkeatasoisissa sotaromaaneissa tapahtuu näyttämällä sodan brutaali kaaos ja tragedia mahdollisimman neutraalisti. Näin teos myös kirjoittuu osaksi sotaromaanin genreä ja on sille uskollinen.

\section{Viitteet}

${ }^{1}$ Käytän jatkossa Marsipansoldaten-romaanista lyhennettä M.

${ }^{2}$ Yksi myyntiluvuin mitattuna menestyksekkäimmistä kotirintamaa kuvaavista kirjailijoista on Laila Hirvisaari (ent. Hietamies). Hänen siviilien elämää Lappeenrannassa 1930- ja 1940-luvuilla kuvaavan seitsenosaisen Lehmusten kaupunki -sarjansa ensimmäiset osat ilmestyivät vuosina 1972-1976 ja jälkimmäiset osat vuosina 2001-2004. http://www. lailahirvisaari.net/ (30.9.2011). Siviilien elämää sodassa kuvataan myös Jörn Donnerin Andersin sukua käsittelevässä romaanisarjassa, jonka ensimmäinen osa $N u$ måste $d u$ ilmestyi vuonna 1974.

${ }^{3}$ Vertailevaa tutkimusta suomalaisen, saksalaisen ja amerikkalaisen sotakirjallisuuden välillä on tehnyt Heikki Siltala (1996). Ks. myös Niemi 1988, 16.

${ }^{4}$ Suomenruotsalaisuuden ja kielikysymyksen terävää analysointia on teoksessa monessa muussakin kohdassa syvemmin sivuhenkilöihin ja instituutioiden kuvaukseen kirjoitettuna (esim. Marthan, Leonardin ja Gunnar Hellénin hahmoissa sekä Frejn upseerikoulukokemuksissa).

\section{Lähteet}

M = Lundberg, Ulla-Lena (2001) Marsipansoldaten. Helsingfors, Söderström \& C:o Förlags Ab.

BAHTIN, MiHAIL I995: François Rabelais - keskiajan ja renessanssin nauru. Alkuteos: Tvorčestvo Fransua Rable i narodnaâ kul'tura srednevekov'â i Renessansa (1965) Moskva: Hudožestvennaâ litertura. Suom. Tapani Laine ja Paula Nieminen. Helsinki: Taifuuni. BJON, SYLVIA I 5.I I.200 I: Tekniskt fel i Marsipansoldaten. Hufvudstadsbladet.

BOURKE, JOANNA 2006: "Uusi sotahistoria". Ihminen sodassa. Suomalaisten kokemuksia talvi-ja jatkosodasta. Toim. Tiina Kinnunen ja Ville Kivimäki. Jyväskylä: Minerva. Dawson, Graham I994: Soldier Heroes. British Adventure, Empire and Imaging of Masculinities. London: Routledge. EKHOLM, KAI 2000: Kielletyt kirjat 1944-1946. Jyväskylä: Things to come.

HALLILla, MIKA 200I: Antiromaanista valtavirtaan: metafiktion käsite ja sen käyttö kirjallisuudessa. Kirjallisuudentutkijain seuran vuosikirja 54, 118-130.

HOSIAISLUOMA, YRJÖ 2003: Kirjallisuuden sanakirja. Helsinki: WSOY. HutCheon, LINDA I988: A Poetics of Postmodernism. London: Routledge. hutcheon, LINDA 1994: Irony's Edge. The Theory and Politics of Irony. London: Routledge.

KANTOKORPI, MERVI I 5.6.2007: Helvi Hämäläisen Raakileet maalaa tylyn kuvan sotien 
nöyryyttämästä Suomesta. Helsingin Sanomat.

KARONEN, VESA 9. I I.2003: Suomalaisen sotakirjan tilannekatsaus. Helsingin Sanomat. KARONEN, VeSA I 4.I I.200 I: Sotahistoria karkasi omille teilleen. Helsingin Sanomat.

KATZ, WENDY R. I980: Some Uses of Food in Children's Literature. Children's Literature in Education, Vol. 11, Nr. 4, 192-199.

KEELING, KARA K. \& POLLARD, SCOTT T. 2009: Introduction: Food in Children's Literature. Critical Approaches to Food in Children's Literature. Eds. Kara K. Keeling \& Scott T. Pollard. New York: Routledge.

KEMPPAINEN, ILONA 2006: Isänmaan uhrit. Sankarikuolema Suomessa toisen maailmansodan aikana. Bibliotheca Historica 102. Helsinki: SKS.

Kemppainen, IlONA \& Peltonen, ulla-Maija 20 Io: Muuttuva sankaruus. Kirjoituksia sankaruudesta. Toim. Ulla-Maija Peltonen \& Ilona Kemppainen. Suomalaisen Kirjallisuuden Seuran Toimituksia 1283. Helsinki: SKS.

KIRVES, JENNI 2008: "Sota ei ollut elämisen eikä muistamisen arvoista aikaa" - kirjailijat ja traumaattinen sota. Ruma sota. Talvi-ja jatkosodan vaiettu historia. Toim. Sari Näre \& Jenni Kirves. Helsinki: Johnny Kniga, 381-425.

коRsströм, тUVA I 6.9.200I: Den finlandssvenska soldatens krönika. Hufuudstadsbladet.

KURIKKA, KAISA 5.I 2.200I: Lundberg uudistaa sotaromaania. Turun Sanomat. LAPPAlainen, PÄIVI 2006: Anarkiasta anoreksiaan. Ruoan merkityksestä lasten- ja nuortenkirjallisuudessa. Täysi kattaus. Ruokaa ja juomaa kirjallisuudessa. Toim. Siru Kainulainen \& Viola Parente-Čapková. Taiteiden tutkimuksen laitos, Sarja A 58. Turku: Turun yliopisto, 126-158.

LAHTONEN, SUVI 20 I I: Sotaromaanin laji ja kirjallinen sankaruus Ulla-Lena Lundbergin romaanissa Marsipansoldaten. Pro gradu -työ, Kotimainen kirjallisuus. Turku: Turun yliopisto. https://www.doria.fi/handle/10024/73975 (19.6.2013)

LASSILA, PERTTI I 4.I I.200 I: Naisen sotaromaani elää kotirintamalla. Helsingin Sanomat. LASSILA, PERTTI I 998: Rauhan kriisi ja kirjallisuuden murros välirauhan jälkeen. Kirjoituksia 1940-luvun kirjallisuudesta ja kulttuurista. Toim. Auli Viikari. Suomalaisen Kirjallisuuden Seuran toimituksia 700. Helsinki: SKS, 9-16.

LEHTO, SILENE \& RANTANEN OUTI I 3.5.2008: Kotirintaman kokemuksia kaunokirjallisuudessa. Helsingin kaupunginkirjaston www-sivu osoitteessa http://www.helmet. fi/fi-FI/Vinkit/Vinkit/Kotirintaman_kokemuksia_kaunokirjallisuu(193) (19.6.2013) LYYTIKÄInen, PIRJo 2008: Maria Jotuni. Klassikkogalleria. Kristiina-instituutin wwwsivu osoitteessa http://www.helsinki.fi/sukupuolentutkimus/klassikkogalleria/jotuni/ (1.10.2013)

MEINANDER, HeNRIK 2009: Suomi 1944. Sota, yhteiskunta, tunnemaisema. Helsinki, Kustannusosakeyhtiö Siltala.

MÄKelë, MATTI I I.I I.200 I: Syöpöt juhlivat sodassa. Aamulehti. 
MÄLKKI, JUHA 2008: Herrat, jätkät ja sotataito. Kansalaissotilas- ja ammattisotilasarmeijan rakentuminen 1920- ja 1930-luvulla "talvisodan ihmeeksi". Bibliotheca Historica 117. SKS, Helsinki.

NIEMI, JUHANi I988: Viime sotien kirjat. Suomalaisen Kirjallisuuden Seuran Toimituksia 475. Helsinki, SKS.

NYKÄNEN, ANNA-STINA I.I 2.2002: Kansa taisteli, kirjat kertovat. Helsingin Sanomat.

NÄRE, SARI 2008: "Kuin viimeistä päivää” - sota-ajan sukupuolikulttuuri ja seksuaalinen väkivalta. Ruma sota. Talvi-ja jatkosodan vaiettu historia. Toim. Sari Näre \& Jenni Kirves. Helsinki, Johnny Kniga, 335-380.

PALOLAMPI, ERKKI I940: Kollaa kestä̈. Kertomuksia Kollaanjoen rintamalta. Helsinki: WSOY.

PertTUla, irma 20IO: Groteski suomalaisessa kirjallisundessa. Neljä tapaustutkimusta. Suomalaisen Kirjallisuuden Seuran Toimituksia 1308. Helsinki: SKS.

PILKE, HELENA 2009: Etulinjan kynämiehet. Suomalaisen sotakirjallisuuden kustantaminen ja ennakkosensuuri kirjojen julkaisutoiminnan sä̈̈ntelijänä 1939-1944. Bibliotheca Historica 123. Helsinki: SKS.

SALIN, SARI 2002: Hullua hurskaampi. Ironinen kahdentuminen Jorma Korpelan romaaneissa. Helsinki: WSOY.

SALIN, SARI 2007: Kun sissiltä meni hermot - Paavo Rintalan Sissiluutnantin epäluotettava kertoja. Avain nro 2, vsk. 2007, 5-23.

SILTALA, JUHA 2006: Sodan psykohistoriaa. Ihminen sodassa. Suomalaisten kokemuksia talvi- ja jatkosodasta. Toim. Tiina Kinnunen ja Ville Kivimäki. Jyväskylä: Minerva, 43-68.

SILTALA, HeIKKI I996: Kolmen rintaman konfliktit. Suomalaisen Kirjallisuuden Seuran Toimituksia. Helsinki: SKS.

SVENSSON, ANITA I 6.9.200I: När kriget blir vardag. Vasabladet.

TEPORA, TUOMAS 2007: Poikien sota. Toisen maailmansodan aikaiset poikien sotakirjat siirtymän kuvauksena. Historiallinen Aikakauskirja, vol. 105., n:o 3, 153-170.

TybJERG, Kristian I996: Min ålandske klangbud. Portræt af Ulla-Lena Lundbergs forfatterskab. Bogens verden nro 3, vsk. 1996. http://www2.kb.dk/guests/natl/db/bv// bv-96/3-96/ty.htm (19.6.2013)

villa, KYLlikKi 2006: Tyttö sodassa. Kenttälotan kirjeitä 1941-1944. Helsinki: Like. WEBB, JEAN 2009: "Voracious Appetites": The Construction of "Fatness" in the Boy Hero in English Children's Literature. Critical Approaches to Food in Children's Literature. Eds. Kara K. Keeling \& Scott T. Pollard. New York/Abingdon: Routledge.

ZILliaCus, ClAS I999: Tunnustus, dokumentti ja raportti kirjallisuuskäsityksen avartajina. Suomen kirjallisuushistoria 3: Rintamakirjeistä tietoverkkoibin. Toim. Pertti Lassila. Suomalaisen Kirjallisuuden Seuran Toimituksia 724:3. Helsinki: SKS. 